\title{
DARI PETANI MENJADI NELAYAN: KAJIAN HISTORIS PERIKANAN TANGKAP PANTAI SELATAN YOGYAKARTA *)
}

\section{FROM FARMERS BECOME FISHERS: A HISTORICAL STUDY OF SOUTH COASTAL YOGYAKARTA MARINE CAPTURE FISHERIES}

\author{
Su a di ${ }^{* *}$
}

\begin{abstract}
The aims of this research were to know the history and development of fisheries activity and its contribution to coastal community welfare at South Coast of Yogyakarta Special Territory Province. To examine these issues the research was conducted by combined survey and descriptive analytic methods. Fisheries in area could be categorized as new activity and historically community does not have a high dependency on marine capture fisheries. Fishers were farmers who become fisherman due to several reasons such as limitation of land and lack of other job opportunity. Since the activity began in the end of 1970's at Baron, marine capture fisheries have altered income sources, improve community houses, and attracted young people as well as provide productivity activity for rural women. In the recent time, marine capture fishery has dispersed to all of Yogyakarta South Coastal area at 19 fish-landing places with vary intensity of resources exploitation. Marine capture fisheries are still limited in the coastal zone. Although CPUE tend to increase, the activity should be extended to province management zone and ZEEI. The integrated policy and management are needed to solve these problems and to avoid the tragedy of the commons.
\end{abstract}

Key words: Historical, Marine Capture Fisheries, and South Coastal of Yogyakarta

\section{Pengantar}

Panjang Pantai Selatan Daerah Istimewa Yogyakarta (DIY) diperkirakan mencapai $110 \mathrm{~km}$ yang tersebar di sepanjang pesisir selatan Kabupaten Gunungkidul, Bantul dan Kulon Progo. Pantai yang berhadapan langsung dengan Laut Hindia tersebut dicirikan oleh daerah pinggir pantai berkarang di Gunungkidul (kurang lebih 70 $\mathrm{km}$ ), dan hamparan pasir di dua kabupaten lainnya. Kegiatan perikanan tangkap di daerah ini masih tergolong baru. Kondisi sosial budaya masyarakat yang secara historis tidak mengenal aktivitas perikanan laut menjadikan kegiatan kenelayanan kurang berkembang.

Berbeda dengan masyarakat di pesisir utara, masyarakat di Pantai Selatan Jawa memperlakukan laut sebagai sesuatu yang bersifat mistik, kecuali bagi masyarakat Madura vana memandana laut sebaaai tempat bekerja dan sumber penghidupan (Whitten dkk. 1999). Kondisi Pantai Selatan DIY dan Jawa yang secara umum dicirikan oleh pantai dengan jalur perairan dangkal yang sempit dan kemudian langsung dengan tajam jatuh pada kedalaman perairan Laut Hindia sering menjadi penghambat pengoperasian alat tangkap (Bailey dkk. 1987).

Walaupun tergolong baru, kegiatan perikanan tangkap di Pantai Selatan DIY semakin berkembang akhir-akhir ini seperti ditunjukkan oleh peningkatan armada dan sebaran daerah penangkapan. Kontribusi positif kegiatan perikanan tangkap terhadap status sosial ekonomi masyarakat telah meningkatkan intensitas eksploitasi sumberdaya, sehingga pengelolaan menjadi sangat penting. Untuk mencapai tujuan pengelolaan yang optimal, selain aspek biologi dan ekologi, penaetahuan tentana karakter masvarakat

\footnotetext{
*) Makalah pada Seminar Nasional Dilema Penerapan Otonomi Daerah dalam Pengelolaan Sumberdaya Alam Berwawasan Lingkungan, Gedung Pasca Sarjana UGM, Yogyakarta, 9 - 11 Agustus 2001

"*Staf Pengajar Jurusan Perikanan UGM, E-mail:suadi@faperta.ugm.ac.id
} 
dan hubungan dengan lingkungannya perlu mendapat perhatian. Tulisan ini bertujuan memaparkan aspek historis perikanan tangkap Pantai Selatan DIY, kontribusinya bagi masyarakat, dan pengembangannya di masa depan.

\section{Bahan dan Metode}

\section{Lokasi Penelitian}

Penelitian dilakukan di Pantai Selatan DIY masing-masing di Pantai Congot, Glagah, Karangwuni, Bugel dan Trisik di Kabupaten Kulon Progo, Pantai Pandansimo, Kuwaru, Samas dan Depok di Bantul, serta Pantai Gesing, Ngrenehan, Baron, Kukup, Drini, Krakal, Sundak, Siung, Wediombo, dan Pantai Sadeng di Gunungkidul.

\section{Pengumpulan Data}

Penelitian menggunakan perpaduan metode survey dan deskriptif analitik. Pengumpulan data dilakukan dengan teknik pencatatan dan indepth interview. Data dikumpulkan dari nelayan sampel, instansi dan pejabat terkait, yang meliputi 1) aktivitas masyarakat di sekitar pesisir selatan DIY, 2) karakter pemanfatan sumberdaya ikan, 3) sarana penangkapan, produksi dan nilainya serta pengembangannya, serta 4) perubahan sosial ekonomi masyarakat pesisir dalam hubungannya dengan aktivitas pemanfaatan sumberdaya ikan. Analisis data dilakukan secara deskriptif (Nazir 1988).

\section{Hasil dan Pembahasan}

\section{Sejarah Perikanan Tangkap}

Nelayan Pantai Selatan DIY adalah kelompok masyarakat petani yang beralih ke aktivitas kenelayanan karena berbagai alasan dan adanya dorongan serta dukungan dari luar. Berbagai keterbatasan di lingkungan sekitarnya di darat (lahan dan pekerjaan) mengharuskan masyarakat menemukan pola strategi adaptasi yang sesuai. Diversivikasi pekerjaan menjadi salah satu alternatif strategi untuk menghadapi kenyataan tersebut. Kusnadi (2000) menyatakan bahwa pola strategi yang seperti ini dan kerterlibatan para istri serta anggota keluarga dalam mencari pekerjaan yang tersedia menjadi pilihan yang ditempuh oleh petani untuk menjaga kelangsungan hidupnya. Keadaan ini sangat nyata terlihat seperti di Pantai Bugel dan Pandansimo yang lahan pertaniannya sering terendam oleh air dengan kadar garam tinggi, atau lahan yang sering kekurangan air di sebagian besar pantai di daerah pesisir Gunungkidul.

Latar belakang nelayan seperti di atas menjadikan perikanan tangkap di Pantai Selatan DIY berbeda dengan umumnya Pantai Utara Jawa. Sebagian besar masyarakat di Pantai Utara memiliki sejarah yang panjang dalam hubungan dengan kegiatan kenelayanan. Mashuri (1996) telah melaporkan dengan rinci tentang peranan sektor perikanan di Pantai Utara Jawa pada periode 1850-1940. Boomgaard (1989) juga seperti dikutip oleh Baiquni (1996) telah menunjukkan bahwa ekonomi pulau Jawa selain ditandai sektor pertanian, juga didominasi kegiatan perikanan dan industri perkapalan yang cukup maju (sebagai sektor primer) yang umumnya tersebar di Pantai Utara Jawa seperti Batavia, Demak, Semarang, Torbaya, Jepara, Rembang, Lasem, Gresik, dan Arosbaya (di Madura), serta Banten dan Cirebon.

Kegiatan perikanan tangkap di laut sebagai mata pencaharian masyarakat pesisir selatan DIY dapat dikategorikan baru. Kelompok masyarakat yang memanfaatkan sumberdaya tersebut secara historis tidak memiliki akar sejarah yang kuat dan ketergantungan yang tinggi terhadap pemanfaatan sumberdaya ikan. Kegiatan perikanan tangkap di Pantai Selatan DIY mulai berkembang pada akhir tahun 1970-an atau awal tahun 1980an di sekitar Pantai Baron Kabupaten Gunungkidul. Kegiatan perikanan di pantai 
tersebut telah menjadi perintis dan mendorong perkembangan perikanan tangkap di seluruh Pantai Selatan DIY. Namun demikian, pada waktu yang sama juga kegiatan ini telah dicoba untuk dikembangkan di Pantai Samas, Bantul dan Pantai Congot, Kulonprogo, tetatpi tidak cukup berkembang pada saat itu. Periode dan perkembangan perikanan tangkap Pantai Selatan DIY secara rinci tersaji pada Tabel 1.

Berdasarkan Tabel 1 terlihat Pantai Baron menjadi titik awal (perintis) kegiatan perikanan tangkap di Pantai Selatan DIY. Pada awal perkembangnya, kegiatan tersebut terbatas di pinggir pantai di sekitar karang-karang terjal dan/atau pantai berpasir. Alat tangkap krendet (penangkap lobster) menjadi alat utama nelayan di Pantai Selatan Gunungkidul sebelum tahun 1980an dan jala serta jaring eret di Pantai Selatan Bantul dan Kulon Progo sebelum pertengahan tahun 1990an. Setelah motorisasi pada pertengahan $1980 a n$, perluasan daerah penangkapan kemudian berkembang, sehingga alat tangkap juga berkembang menjadi jaring insang, trammel net, pancing dan pelintur. Alat tangkap sederhana seperti krendet dan jaring eret masih digunakan oleh nelayan sampai saat ini terutama bagi nelayan yang tidak memiliki perahu atau menjadi ABK.

Dengan sejarah yang agak panjang, Pantai Baron telah menjadi daerah perikanan tangkap yang paling maju dibandingkan dengan daerah lainnya di Pantai Selatan DIY. Kegiatan perikanan juga secara sinergis telah berkembang bersama pariwisata di pantai ini. Sebagai hasilnya, terjadi peningkatan secara signifikan status sosial ekonomi masyarakat seperti tercermin dari perubahan perumahan atau tempat tinggal nelayan, dari rumah semi permanen menjadi rumah permanen dan berlantai keramik.

Kontribusi pendapatan usaha perikanan tangkap di Pantai Selatan DIY terhadap total pendapatan nelayan cukup signifikan.
Daerah dengan kegiatan perikanan tangkap yang lebih awal berkembang menunjukkan kontribusi yang lebih besar terhadap pendapatan nelayan dibandingkan dengan yang berkembang kemudian. Kontribusi perikanan tangkap terhadap pendapatan nelayan di Pantai Selatan Gunungkidul mencapai $75,5 \%$, sedangkan di Bantul dan Kulon Progo masing-masing $68,27 \%$ dan $41,32 \%$ (Kamiso dkk. 2000)

Usaha perikanan tangkap di Pantai Selatan DIY juga telah menarik kelompok usia produktif, dengan usia rata-rata 20-40 tahun, terlibat di dalamnya. Bagi kaum wanita, usaha ini telah menyediakan lapangan kerja di pedesaan. Widaningroem dkk. (1999) melaporkan bahwa wanita di daerah tersebut menempati berbagai posisi dalam mata rantai tata niaga hasil perikanan seperti menjadi bakul, pengolah, pengemas dan penyaji. Di Pantai Gesing, wanita berperan dalam mengelola lahan pertanian ketika para suami menangkap lobster yang bertepatan dengan musim tanam.

Walaupun terlihat kontribusi yang besar usaha berikanan bagi masyarakat peisisir, tidak ditemukan adanya pola pergantian total mata pencaharian, sehingga aktivitas baru (kenelayanan) dan aktivitas yang sudah lama (pertanian) menjadi kegiatan yang saling mempertukarkan. Pada beberapa kasus seperti di Pantai Baron ditemukan adanya pola penyerahan pengelolaan lahan pertanian ke orang lain yang dilakukan oleh para nelayan agar dapat mengosentrasikan diri pada usaha nelayan. Waktu melaut yang tidak terlalu panjang juga mendukung pola kegiatan seperti ini.

Selain beberapa upaya yang dilakukan oleh pemerintah melalui pelatihan dan pemberian kredit, serta keterlibatan perguruan tinggi, khususnya Jurusan Perikanan UGM dalam kegiatan studi, transfer informasi dan pemberdayaan, nelayan andon (dari luar daerah) mempunyai kontribusi besar terhadap keterlibatan masyarakat pesisir selatan 
Tabel 1. Periode dan Perkembangan Kegiatan Perikanan Tangkap di Pantai Selatan Daerah Istimewa Yogyakarta, Tahun 1980-2000

\begin{tabular}{|c|c|}
\hline Periode & Ciri / Karakter Kegiatan Perikanan \\
\hline $\begin{array}{l}\text { Sebelum } \\
1980-A n\end{array}$ & $\begin{array}{l}\text { - Perikanan belum cukup nampak, walaupun ada penangkapan ikan hias } \\
\text { - Mulai pengkajian pengembangan sawah tambak } \\
\text { - Masyarakat tergantung pada kegiatan pertanian } \\
\text { - Pemukiman pesisir masih nampak sederhana }\end{array}$ \\
\hline $1981 / 1982$ & $\begin{array}{l}\text { - Kegiatan terdiversifikasi ke arah laut } \\
\text { - Kegiatan perikanan dengan alat tangkap sederhana berkembang } \\
\text { - Alat tangkap Krendet menjadi alat tangkap utama dengan lobster sebagai spesies } \\
\text { target } \\
\text { - Kegiatan terbatas di pinggir pantai } \\
\text { - Masyarakat di sekitar Pantai Baron menjadi perintis kegiatan perikanan tangkap } \\
\text { - Perikanan tangkap juga coba dikembangkan di Pantai Samas dan Congot tetapi } \\
\text { tidak berkembang }\end{array}$ \\
\hline $1984 / 1985$ & $\begin{array}{l}\text { - Motorisasi mulai berkembang } \\
\text { - Alat tangkap berkembang menggunakan jaring insang } \\
\text { - Alat tangkap krendet masih digunakan nelayan } \\
\text { - Dukungan pemerintah daerah meningkat } \\
\text { - Nelayan banyak yang dilatih } \\
\text { - Peranan nelayan andon Cilacap dan Gombong cukup nampak } \\
\text { - Kegiatan perikanan berkembang di pantai sekitar Baron seperti Pantai Ngrenehan } \\
\text { dan kemudian Sadeng } \\
\text { - Rumput laut diusahakan }\end{array}$ \\
\hline $\begin{array}{c}\text { Akhir } 1980 \\
(1987 / 1989)\end{array}$ & $\begin{array}{l}\text { - Pengkajian potensi dan pengembangan telah dilakukan } \\
\text { - Perikanan lobster semakin berkembang } \\
\text { - Perumahan nelayan mulai meningkat } \\
\text { - Investasi semakin berkembang dan Ngrenehan mulai maju } \\
\text { - Pendaratan ikan Baron semakin maju } \\
\text { - Pencatatan hasil dan nilai produksi membaik }\end{array}$ \\
\hline $1991 / 1993$ & $\begin{array}{l}\text { - PPI Sadeng dibangun } \\
\text { - PPI cukup ramai pada awal dibangun } \\
\text { - Produksi PPI Sadeng menurun karena berbagai permasalahan } \\
\text { - Pantai baron juga berkembang untuk pariwisata } \\
\text { - Perikanan ikan hias dikembangkan di Pantai Kukup }\end{array}$ \\
\hline $1995 / 1996$ & $\begin{array}{l}\text { - Aktivitas penangkapan berkembang di Pantai Selatan Bantul } \\
\text { - Pantai pandansimo dan Depok menjadi perintis di Kabupaten Bantul } \\
\text { - Sarana penangkapan mencapai } 58 \text { unit perahu motor di Depok } \\
\text { - Pantai Baron sangat menonjol dengan kegiatan bersama pariwisata dan } \\
\text { perikanan tangkap }\end{array}$ \\
\hline $1997-2000$ & $\begin{array}{l}\text { - Harga udang barong melambung tinggi (mencapai Rp } 250.000,00 \text { ) } \\
\text { - Perumahan nelayan semakin meningkat } \\
\text { - Daerah penangkapan dan TPI baru berkembang di Pantai Selatan Kabupaten } \\
\text { Kulon Progo (Pantai Trisik, Bugel dan Glagah) } \\
\text { - Produksi lobster cenderung menurun dan ukuran semakin mengecil } \\
\text { - Daerah penangkapan ikan telah tersebar di } 19 \text { Pantai di selatan DIY, } 16 \\
\text { diantaranya memiliki TPI, namum upaya exploitasi belum merata } \\
\text { - Antusiasme masyarakat dan Pemda sangat tinggi terhadap kegiatan perikanan } \\
\text { tangkap di laut } \\
\text { - Koperasi nelayan juga berkembang } \\
\text { - Tuntutan pembangunan pelabuhan lepas pantai sangat menonjol } \\
\text { - Kegiatan terbatas di pingir pantai dan pantai (kurang dari } 4 \text { mil) } \\
\text { - Jumlah nelayan mencapai } 1804 \text { orang } \\
\text { banyaknya nelayan andon dari Pacitan, Gombong, Cilacap } \\
\end{array}$ \\
\hline
\end{tabular}


DIY dalam aktivitas perikanan tangkap. Nelayan Cilacap dan Gombong, Jawa Tengah, telah menjadi inspirator dan motivator perubahan aktivitas dari sepenuhnya tergantung pada kegiatan bertani menjadi terdiversivikasi ke kegiatan kenelayanan. Kegiatan perikanan tangkap tersebut telah tersebar di Pantai Selatan Bantul pada 1995 dan di Pantai Selatan Kulon Progo pada tahun 1997, walaupun dengan intensitas yang beragam dalam pemanfataatan sumberdaya.

Total nelayan di pantai selatan DIY diperkirakan 1804 orang, baik nelayan yang mempunyai perahu maupun tidak (Kamiso dkk. 2000). Berdasarkan tingkat pendidikan beragam, nelayan di Pantai Selatan Bantul memiliki tingkat pendidikan yang cukup baik masing-masing 40,25\% SD, $17,5 \%$ SLTP, $20 \%$ SMU, dan sekitar $20 \%$ pendidikan tinggi, sedangkan di Kulom Progo masing-masing $45,6 \%$ SD, $31,4 \%$ SLTP dan 22\% SMU. Dengan struktur seperti ini, pengelolaan dan pengembangan perikanan tangkap di pantai selatan DIY akan di dukung oleh sumberdaya manusia yang cukup memadai.

\section{Status Pemanfaatan dan Pengembangan Perikanan Tangkap}

Secara umum kegiatan perikanan dunia termasuk pantai telah terbebani berlebihan. Hasil beberapa kajian menunjukkan bahwa tingkat pemanfaatan sumberdaya ikan telah mendekati ekploitasi yang maksimum dari potensi lestarinya dan perlu pengelolaan yang serius (Crus dan Tirnidad 1993; Nurhakim dkk. 1994; Pitcher 1996). Charles (2001) dengan mengutip hasil laporan FAO (1997) menunjukkan bahwa sekitar 60\% perikanan utama dunia telah mengalami eksploitasi yang berlebihan. Kondisi ini telah berakibat pada berbagai krisis seperti krisis biologi, ekologi, ekonomi dan sosial (Cohrane 2000). Walaupun kenyataan ini belum cukup terlihat di Pantai Selatan DIY, namun kehati-hatian sangat diperlukan.
Kegiatan perikanan tangkap di Pantai Selatan DIY termasuk perikanan skala kecil. Karakter kegiatan perikanan yang masih terbatas di wilayah pantai dengan alat yang beragam dan sarana penangkapan berupa perahu motor outboard merupakan beberapa ciri perikanan skala ini (Bailey 1988; Charles 2001). Nelayan skala kecil juga merupakan kelompok masyarakat nelayan terbesar dalam komunitas masyarakat pesisir. Kondisi tersebut menjadikan sumberdaya ikan sangat mudah dieksploitasi secara berlebihan.

Total perahu motor di Pantai Selatan DIY berjumlah 316 unit masing-masing 168 unit di Pantai Selatan Gunungkidul, 112 unit di Bantul, dan sekitar 36 unit di Kulon Progo. Jumlah perahu motor tersebut akan meningkat pada musim ikan (bulan September-Mei) disebabkan banyaknya nelayan andon yang menangkap ikan di sekitar Pantai Selatan DIY. Perahu motor di daerah tersebut umumnya memiliki panjang rata-rata $8 \mathrm{~m}$, dalam dan lebar 1 $\mathrm{m}$, serta dilengkapi dengan cadik dan motor tempel berkekuatan 15-25 PK. Alat tangkap yang digunakan antara lain berupa jaring insang, pelintur, krendet, dan pancing. Lama trip rata-rata 5-6 jam, dengan jumlah trip sangat beragam dimasing-masing daerah pengamatan dengan kisaran rata-rata 150-180 trip/tahun.

Kondisi perikanan tangkap seperti diuraikan di atas cukup berbeda dengan Pantai Selatan Cilacap. Nelayan Pantai Selatan Cilacap dengan jenis perahu yang sama dengan DIY dapat melaut lebih dari 6 jam/trip dengan dua kali trip dalam sehari masing-masing pada pagi hari sampai siang dan sore sampai tengah malam. Kapal ukuran yang agak besar (15-30 GT) dapat berlayar satu minggu sampai satu bulan. Daerah penangkapan ikan nelayan tersebut juga mencapai Pantai Selatan DIY. Keadaan usaha perikanan seperti ini dan didukung oleh pengalaman melaut, sarana penangkapan dan fasilitas pendaratan telah menghasilkan usaha perikanan yang cukup maju. Total produksi 
ikan laut di Pantai Selatan Cilacap mencapai 8.372 ton dan nilai total $\mathrm{Rp} \mathrm{46,4}$ milyar pada tahun 1998 (Anonim 2000b), sedangkan di DIY pada tahun 1999 hanya mencapai 1.184 ton dengan total nilai $\mathrm{Rp}$ 6,7 milyar (Anonim 2000a). Disamping itu, total jumlah uang yang berputar untuk kebutuhan konsumsi ABK, bahan bakar kapal, es dan kebutuhan lainnya di Pelabuhan Perikananan Nusantara Cilacap (PPNC) dapat mencapai Rp 1 milyar per hari.

Kecenderungan hasil tangkapan per satuan upaya (Catch Per Unit of Effort atau
CPUE) di Pantai Selatan DIY terlihat masih meningkat. Kecenderungan seperti ini sering digunakan untuk memprediksi hubungan antara upaya penangkapan dengan ketersediaan stok sumberdaya atau masa depan perikanan. Panayatou (1992) menjelaskan bahwa evaluasi upaya penangkapan sangat penting karena merupakan parameter utama yang dapat dikontrol oleh manusia. Kecenderungan CPUE di Pantai Selatan DIY berdasarkan hasil perhitungan data di TPI Baron tersaji pada Gambar 1.

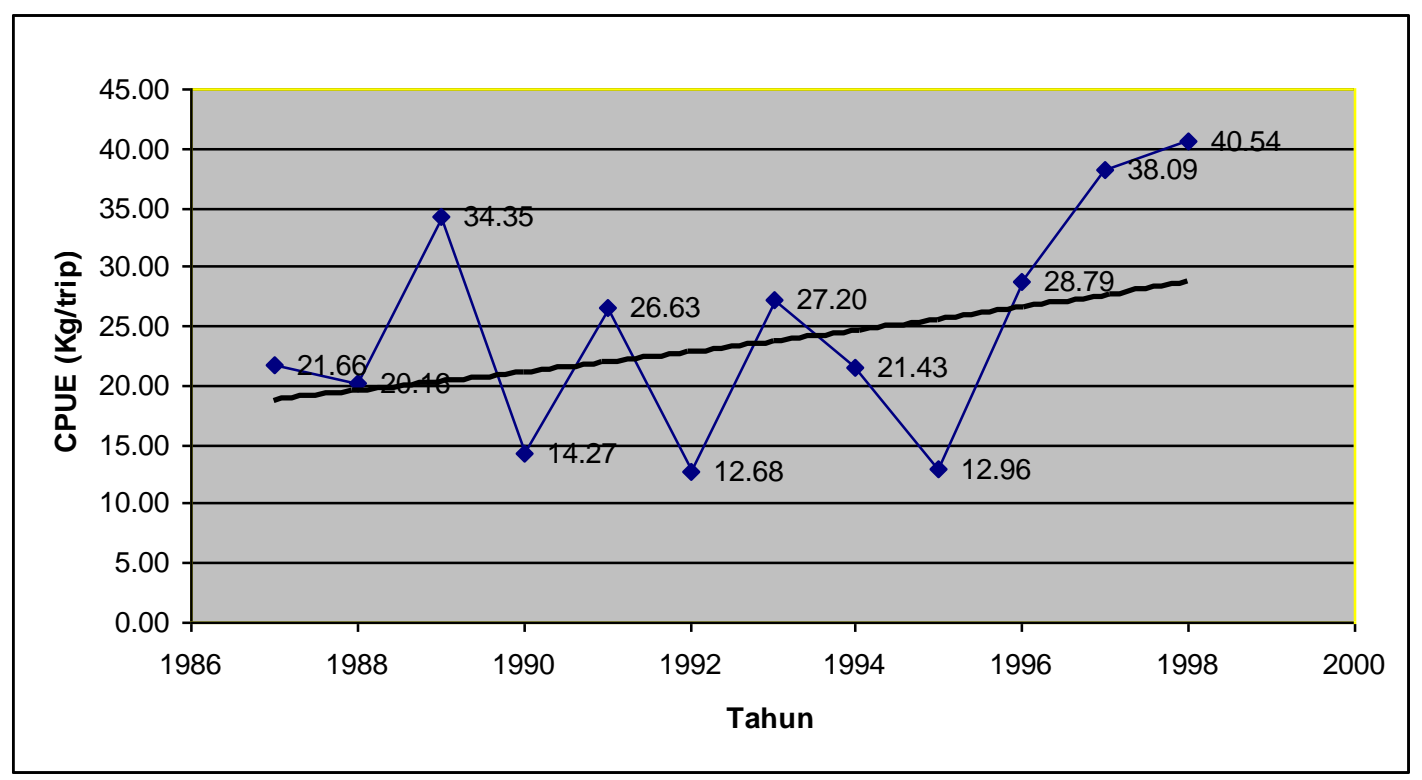

Gambar 1. Kecenderungan CPUE di Pantai Selatan Daerah Istimewa Yogyakarta (Sumber: Analisis Data TPI Baron, 2000)

Berdasarkan Gambar 1 terlihat CPUE yang berfluktuasi dari tahun 1988 sampai periode pertengahan tahun 2000 dengan kecenderungan yang meningkat. Kecenderungan ini mengindikasikan bahwa perluasan usaha penangkapan dapat dilakukan dengan alat tangkap yang digunakan oleh nelayan saat ini. Namun demikian, beberapa jenis ikan telah tereksploitasi melebihi yang diperkenankan seperti lobster (Suadi dkk. 2001).
Perluasan daerah penangkapan pada perairan lepas pantai dan samudra melalui peningkatan sarana dan prasarana penangkapan ikan dan didukung pendaratan ikan yang memadai akan memberikan hasil yang lebih baik dan berkelanjutan bagi nelayan, pemerintah daerah dan sumberdaya di masa mendatang. Upaya perluasan daerah penangkapan pada wilayah pengelolaan propinsi (menurut UU 22/1999) dan zona ekonomi eksklusif Indonesia (ZEEI) di 
selatan DIY masih menghadapi beberapa kendala. Kondisi fisik pantai dengan perairan dangkal yang tidak terlalu lebar serta adanya gelombang besar (pada musim tenggara pada bulan JuniSeptember) sering menjadi penghambat upaya perluasan daerah penangkapan tersebut. Armada penangkapan ikan dengan perahu fiberglass dengan kapasitas 15-25 PK juga belum memungkinkan perluasan daerah penangkapan tersebut. Namun demikian besarnya potensi sumberdaya ikan dan tingginya antusiasme masyarakat dan pemerintah daerah mendorong Kamiso dkk. (2000) merekomendasikan dibangunnya pelabuhan perikanan lepas pantai dan/atau samudra

\section{Kesimpulan}

1. Perikanan tangkap sebagai mata pencaharian bagi masyarakat pesisir selatan DIY tergolong baru. Usaha ini berkembang diakhir tahun 1970an dan telah memberikan kontribusi sosialekonomi yang nyata bagi masyarakat.

2. Daerah penangkapan ikan telah tersebar di seluruh wilayan pantai selatan di sekitar 19 lokasi pendaratan ikan masing-masing di Kabupaten Kulon Progo, Bantul dan Gunungkidul dengan intensitas yang beragam. Total nelayan diperkirakan mencapai 1804 orang dan perahu motor berjumlah 316 buah.

3. Perkembangan usaha perikanan yang baik tidak secara langsung mengubah secara total mata pencaharian masyarakat dari petani menjadi nelayan penuh, tetapi kegiatan tersebut saling mempertukarkan. Peranan wanita dalam kegiatan pasca panen dan/atau menukarkan posisi suami dalam kegiatan pertanian nampak nyata di daerah tersebut.

4. Usaha perikanan pantai masih dapat dikembangkan. Perluasan penangkapan di areal lepas pantai dan samudra dan didukung pendaratan atau pelabuhan perikanan lepas pantai dan samudra yang memadai memberikan hasil yang lebih baik di masa mendatang bagi sumberdaya masyarakat dan pemerintah daerah setempat.

\section{Ucapan Terima Kasih}

Ucapan terima kasih disampaikan kepada Proyek Studi Rencana Pembangunan Pelabuhan Pantai Selatan DIY yang telah memberikanan dukungan dana dan data. Prof. Dr. Kamiso HN selaku ketua tim studi tersebut, Soeparno, S.Pi dan Eko Setyobudi, M.Si. atas kerja sama dan diskusinya serta para asisten lapangan, Veni, Ucok, Zaelani, Bucan, Ika, Wanti dan Gugun.

\section{Daftar Pustaka}

Anonim. 1999a. Laporan Tahunan Dinas Perikanan Daerah Istimewa Yogyakarta. Dinas Perikanan Propinsi Daerah Istimewa Yogyakarta.

\section{-----. 2000b. Laporan Statistik Perikanan Pelabuhan Perikanan Nusantara Cilacap 1994-1999. Direktur Jenderal Perikanan. Jakarta.}

Bailey, C., 1988. The Political Economy of Marine Fisheries Development in Indonesia Indonesia: 23-38. Cornell Southeast Asia Program.

Bailey, C., A. Dwiponggo, F. Marahuddin, 1987. Indonesia Marine Capture Fisheries. ICLRAM Studies and Review No. 10. Manila dan Jakarta.

Baiquni, M., 1996. Eko-Geografi Wilayah Pantai: Dinamika Sosial Ekonomi Pengusahaan Lahan Pantai di Indonesia. Paper Seminar Nasional Tata Guna Lahan dan Penggunaan Air untuk Pembangunan Perikanan di Abad XXI. Keluarga Mahasiswa IImu Perikanan UGM, 10 Desember 1996. Yogyakarta. 
Charles, A.T. 2001. Sustainable Fishery System. Blackwell Science Ltd. London. 370 hal.

Cohrane, K.L. 2000. Reconciling Sustainability, Econoic Efficiency and Equity in Fisheries: The One that Got Away? Fish and Fisheries (I): 3-21.

Cruz, A. dan Trinidad. 1993. Economic Exploitation in the Philippine Small Pelagic Fishery and Implications for Management. Naga The ICLARM Qualterly (4): 13-15.

Kamiso, H.N., Suadi, Triyanto, Supardjo SD, B. Triatmodjo, Nizam, 2001. Studi Rencana Pembangunan Pelabuhan Perikanan di Propinsi Daerah Istimewa Yogyakarta. Laporan Akhir. PUSTEK Kelautan UGM - Dinas Perikanan Propinsi Daerah Istimewa Yogyakarta.

Kusnadi, A. 2000. Nelayan: Strategi Adaptasi dan Jaringan Sosial. Humaniora Utama Press Bandung. 244 hal.

Mashuri. 1996. Menyisir Pantai Utara: Usaha dan Perekonomian Nelayan di Jawa dan Madura 1850-1940. Yayasan Pustaka Nusantara.

Nazir, M. 1988. Metode Penelitian, Cetakan III, Ghalia Indonesia. Jakarta.

Nurhakim, S., B. Sadhotomo, M. Potier. Composite Model on Small Pelagic Resources. Dalam Biodynex: Biology, Dynamic, Exploitation of the Small Pelagic Fishes in the Java Sea. M. Potier dan S. Nurhakim (Ed). Pelfish. Jakarta. Hal:145-153.

Panayatou, T. 1992. Management Concepts for Small Scale Fisheries: Economic and Social Aspects. FAO Fisheries Technical Paper. Rome. 53 hal.

Pitcher, A. 1996. Reinventing Fisheries Management. Naga The ICLARM Qualterly (7) : 15-17.
Suadi, R. Widaningroem, Soeparno, N Probosunu. 2001. Kajian Sumberdaya Lobster di Pantai Selatan Daerah Istimewa Yogyakarta. J. IImu-IImu Perairan dan Perikanan Indonesia Edisi Khusus Crustacea I (2): 33-42.

Whitten, T., R.E. Soeriatmaja, S.A. Affif 1999. Ekologi Jawa dan Bali. Alih Bahasa S.N. Kartiksari, T.B. Utami, A.Widhyantoro. Prenhallindo. Jakarta. Hal: 673-674.

Widaningroem, R., H. Saksono, S. Kanoni. 1999. Strategi Wanita Mata Rantai Perdagangan Hasil Perikanan di Daerah Istimewa Yogyakarta. Jurnal Gender I (1): 15-29. 